\title{
A novel mutation in the hepatocyte nuclear factor-1 $\beta$ gene in maturity onset diabetes of the young 5 with multiple renal cysts and pancreas hypogenesis: A case report
}

\author{
YOU LV ${ }^{1}$, ZHUO LI $^{1}, \mathrm{KAN} \mathrm{HE}^{2}$, YING GAO ${ }^{1}$, XIANCHAO XIAO ${ }^{1}$, YUJIA LIU $^{1}$ and GUIXIA WANG ${ }^{1}$ \\ Departments of ${ }^{1}$ Endocrinology and Metabolism, and ${ }^{2}$ Radiology, \\ The First Hospital of Jilin University, Changchun, Jilin 130021, P.R. China
}

Received July 18, 2016; Accepted April 11, 2017

DOI: $10.3892 /$ etm.2017.4871

\begin{abstract}
A 17-year-old Chinese male was hospitalized exhibiting hyperglycemia and increased serum urea nitrogen and creatinine levels in addition to weight loss. The patient was treated with gliclazide. The patient was $150 \mathrm{~cm}$ tall, weighed $35 \mathrm{~kg}$ and had no family history of diabetes or kidney disease. Physical examination revealed cephalus quadratus, rachitic rosary and a visible toe-out gait. Laboratory examinations revealed that the patient's fasting plasma glucose and glycosylated hemoglobin levels were markedly increased, fasting plasma C-peptide level was slightly increased and no peak $2 \mathrm{~h}$ postprandial was observed. Diabetic autoimmune antibodies [islet cell cytoplasmic autoantibodies (ICA), glutamic acid decarboxylase autoantibodies (GADA), isulinoma-2-associated autoantibodies (IA2A) and insulin autoantibodies (IAA)] were negative. Levels of serum electrolytes decreased, uric acid and parathyroid hormone increased, mild albuminuria was detected and there was a low proportion of urine. The patient also presented with low bone mass and cataracts. Abdominal computed tomography (CT) revealed a bilateral atrophic kidney with multiple renal cysts, primarily located at the junction of renal cortex and medulla, with a diameter of 0.3-0.7 cm. CT also revealed hypogenesis of the body and tail of the pancreas. In an oral glucose tolerance test, the mother and paternal uncle of the patient were diagnosed with type II diabetes and the patient's sister, maternal uncle and paternal grandpa were diagnosed with glucose tolerance impairment. Genetic testing revealed an unreported amino acid mutation in exon 2 of hepatocyte nuclear factor $1 \beta$ (c.391C>T), a nonsense mutation of CAA
\end{abstract}

Correspondence to: Professor Guixia Wang, Department of Endocrinology and Metabolism, The First Hospital of Jilin University, 71 Xinmin Street, Changchun, Jilin 130021, P.R. China E-mail: gxwang6688@yahoo.com

Key words: hepatocyte nuclear factor-1 $\beta$, maturity onset diabetes of the young 5 , renal cysts, pancreas hypogenesis, mutation to TAA at codon 131. This mutation was identified in the proband but not in any other family members.

\section{Introduction}

Maturity-onset diabetes of the young (MODY) is an inherited type of familial diabetes, which was first recognised by Tattersall in 1974 (1). Several monogenic forms of MODY have been identified, including MODY1-hepatocyte nuclear factor-4 $\alpha$ (HNF4A), MODY2-glucokinase (GCK), MODY3-HNF1A, MODY4-pancreatic and duodenal homeobox 1 (PDX1) and MODY5-HNF1B (2). Carboxyl ester lipase (CEL) and paired box 4 (PAX4) have also been reported to be associated (3). MODY accounts for $1-2 \%$ of all diabetes cases (4) and a previous study documented that MODY represents $2.5 \%$ of all cases in UK pediatric diabetic patients (5). It presents differently, depending on the subtype of MODY diagnosed; MODY1 exhibits a progressive $\beta$ cell dysfunction, fetal macrosomia and neonatal hypoglycaemia, it's sensitive to sulphonylureas. MODY 2 presented with a stable $\beta$ cell function and mild hyperglycemia, that does not respond to oral hypoglycemic agents. MODY3 exhibits a progressive decline in glycemic control but may respond to sulfonylureas $(3,6,7)$. Among different types of maturity-onset diabetes of the young (MODY), variations in hepatocyte nuclear factor (HNF) $1 \beta$ is the type most frequently associated with maturity-onset diabetes of the young 5 (MODY5) (8). The prevalence of MODY5 amongst those with MODY is $5 \%$ (3). HNF-1 $\beta$ is a subtype of monogenic form of diabetes mellitus characterized by autosomal dominant inheritance and the early onset of hyperglycemia, typically when patients are $<25$ years old (9). HNF-1 $\beta$ is encoded by the transcription factor 2 gene and serves an important role in the tissue specific regulation of gene expression in various organs, including the liver, kidney and pancreatic islets, as well as during gut development $(3,10)$. The most common phenotypes of the HNF-1 $\beta$ mutation are renal cysts and diabetic syndromes $(11,12)$. A previous study investigating the HNF-1 $\beta$ mutation revealed that $9 \%$ of affected adult patients presented with chronic renal failure of unknown origin (13). The present study documented a novel HNF-1 $\beta$ nonsense mutation in a 17 -year-old Chinese male with multiple renal cysts and pancreas hypogenesis. 


\section{Case report}

\section{Methods}

Blood sample collection and analysis. The patient fasted for 8-10 h prior to blood sample collection. Blood was drawn into vacuum blood collection tubes without anticoagulant. The sample was inverted several times to mix blood and then chilled immediately by placing in a refrigerator. Plasma was separated from cells by centrifugation $\left(3,000 \mathrm{x} \mathrm{g}, 5 \mathrm{~min}, 37^{\circ} \mathrm{C}\right)$ as soon as possible and within $4 \mathrm{~h}$ after collection. Then the upper supernatant was used for testing. Serum urea nitrogen was measured using the UV-GLDH method (4505-40-2013; Shanghai Kehua Bio-Engineering Co., Ltd., Shanghai, China). Creatinine was measured using the Sarcosine Oxidase-PAP method (4502-40-2013; Shanghai Kehua Bio-Engineering Co., Ltd.). Glucose was measured using the GOD-PAP method (1801-40-2013; Shanghai Kehua Bio-Engineering Co., Ltd.). A Roche Modular Analytics Immunoassay Analyzer e602 and Roche ECLIA kits (11731459122; Roche Diagnostics, Basel, Switzerland) were used to test the serum thyroid-stimulating hormone (TSH) level. UniCel Dxl-800 Automated Chemiluminescent Analyzer (Beckman Coulter, Inc., Brea, CA, USA) and CLIA reagents to test the serum growth hormone (GH, 33580), prolactin (PRL, 33530), luteinizing hormone (LH, 33510) and follicle-stimulating hormone (FSH, 33520) levels.

Oral glucose tolerance test (OGTT). The patient received $75 \mathrm{~g}$ of anhydrous glucose in $225 \mathrm{ml}$ of water in the sitting position after an overnight fasting. Serum samples were collected at 0, 30, 60, 120 and $180 \mathrm{~min}$. Glucose was measured using the aforementioned method. Serum insulin (12017547122; Roche Diagnostics) and serum C-peptide (03184897190; Roche Diagnostics) were measured by ECLIA.

Renal biopsy. The biopsy was performed by a nephrologist. The patient was positioned so that he laid on his stomach. This kept his kidneys easily accessible from his back. A nephrologist injected $5 \mathrm{ml}$ lidocaine (Shanghai Zhaohui Pharmaceutical Co., Ltd., Shanghai, China) into the entry site to numb the area and made a small incision. Then the nephrologist inserted the needle through the incision and into the kidney. This process was operated under an ultrasound scan to direct the needle. The patient took a deep breath and held it as the physician took the tissue sample. Immediately after the biopsy, the puncture site was pressed firmly for $15 \mathrm{~min}$, and then a pressure dressing was applied. After $24 \mathrm{~h}$, if there were no problems, the pressure dressing was removed and the patient was allowed to get out of bed. For optical microscopy, tissue samples were fixed with $10 \%$ formalin solution for 4-6 $\mathrm{h}$ at room temperature, embedded with paraffin, and continuously sectioned into $1 \mu \mathrm{m}$ thick sections. Then periodic acid-Schiff and periodic acid silver methenamine staining were performed.

Periodic acid-schiff staining. The sections were oxidized in $1 \%$ periodic acid solution for $15 \mathrm{~min}$, then rinsed in distilled water. Sections were placed in Schiff reagent for $30 \mathrm{~min}$ at room temperature and in sulphurous acid water for $5 \mathrm{~min}$, then washed in tap water for $5 \mathrm{~min}$. Sections were counterstained in Mayer's hematoxylin for $5 \mathrm{~min}$ at room temperature then placed in ammonia water for $1 \mathrm{~min}$. Slides were dehydrated and coverslips were applied.

Periodic acid silver methenamine staining. The sections were oxidized in $1 \%$ periodic acid solution for $15 \mathrm{~min}$ at room temperature, then placed in $5 \%$ potassium dichromate for $30 \mathrm{~min}$ and in $1 \%$ onatrium bisulfurosum for $1 \mathrm{~min}$. Slides were incubated in methenamine silver working solution for $1 \mathrm{~h}$ at $70^{\circ} \mathrm{C}$, then rinsed in distilled water and toned in $0.2 \%$ gold chloride solution for $1 \mathrm{~min}$. Slides were rinsed in distilled water and treated with $3 \%$ sodium thiosulfate solution for $1 \mathrm{~min}$, then washed in tap water for $10 \mathrm{~min}$. Slides were counterstained in nuclear fast red or light green for $5 \mathrm{~min}$ at room temperature. Slides were dehydrated, cleared in xylene and coverslips were applied.

Immunofluorescence. Frozen renal tissues were sectioned into $5 \mu \mathrm{m}$ thick sections and dried for $40 \mathrm{~min}$ at room temperature. The sections were rinsed three times in PBS. Sections were blocked with non-immune sheep serum (Fuzhou Maixin Biotech. Co., Ltd., Fuzhou, China) for 10 min at room temperature, and directly stained with the corresponding Rabbit anti-human IgG, IgA, IgM, C3, C4, C1q and fibrinogen antibodies (1:20; Dako; Agilent Technologies, Inc., Santa Clara, CA, USA) labeled with fluorescein isothiocyanate for $60 \mathrm{~min}$ at room temperature. Sections were rinsed three times in PBS, then the deposit position/intensity was detected by fluorescence microscopy.

Transmission electron microscopy (TEM). Renal tissue samples were fixed with $3 \%$ glutaraldehyde for $2 \mathrm{~h}$ at $4^{\circ} \mathrm{C}$ and $1 \%$ osmium tetroxide for $1.5 \mathrm{~h}$ at $4^{\circ} \mathrm{C}$. Samples were dehydrated with $50,70,80,90,100 \%$ ethanol for 15 min each, with $100 \%$ ethanol and acetone (1:1) for $10 \mathrm{~min}$ and with $100 \%$ acetone for $10 \mathrm{~min}$. The samples were infiltrated with epoxy resin and acetone (1:1) for $2 \mathrm{~h}$ at room temperature. The sections were embedded in epoxy resin at $45^{\circ} \mathrm{C}$ for $12 \mathrm{~h}$ and at $60^{\circ} \mathrm{C}$ for $48 \mathrm{~h}$. A Leica microtome was used to slice the samples into 50-70 nm sections. Samples were stained with uranyl acetate for $1 \mathrm{~h}$ and lead for $10 \mathrm{~min}$ at room temperature. A JEM-100 electron microscope (JEOL, Ltd., Tokyo, Japan) was used to observe the sample.

Polymerase chain reaction (PCR). DNA was extracted from peripheral blood using the TIANamp Blood DNA kit (Tiangen Biotech Co., Ltd., Beijing, China) and amplified using Taq DNA polymerase (Takara Biotechnology Co., Ltd.). PCR was performed using specific primers of the HNF1B gene, which were HNF1B-2F (5'-GGGGCAGTCACCTTCTCC T-3') and HNF1B-2R (3'-GGGGGCTGTGACTGAAGA ACAT-5'). Thermocycling conditions were as follows: $95^{\circ} \mathrm{C}$ for $5 \mathrm{~min}$, followed by 10 cycles of denaturation at $95^{\circ} \mathrm{C}$ for $30 \mathrm{sec}$, annealing at $63^{\circ} \mathrm{C}$ for $30 \mathrm{sec}$ (reduced by $0.5^{\circ} \mathrm{C}$ per cycle) and extension at $72^{\circ} \mathrm{C}$ for $30 \mathrm{sec}$. A further 30 cycles were performed as follows: denaturation at $95^{\circ} \mathrm{C}$ for $30 \mathrm{sec}$, annealing at $58^{\circ} \mathrm{C}$ for $30 \mathrm{sec}$ and extension at $72^{\circ} \mathrm{C}$ for $30 \mathrm{sec}$. A final extension was performed at $72^{\circ} \mathrm{C}$ for $5 \mathrm{~min}$.

DNA sequencing. The PCR samples were sequenced with $\mathrm{ABI}$ 3730 genetic analyzer (Applied Biosystems; Thermo Fisher 
Scientific, Inc., Waltham, MA, USA) and the results were analyzed using ABI Sequence Scanner Software v1.0 (Applied Biosystems; Thermo Fisher Scientific, Inc. The positive mutation was retested with another separated sample.

Patient admission and diagnosis. A 17-year-old Chinese male was admitted to The First Hospital of Jilin University (Changchun, China) in January 2013, due to hyperglycemia (random plasma glucose was $24.66 \mathrm{mmol} / \mathrm{l}$, reference range: 3.9-6.1 $\mathrm{mmol} / \mathrm{l})$, increased serum urea nitrogen $(17.87 \mathrm{mmol} / \mathrm{l}$, reference range: $3.2-7.0 \mathrm{mmol} / \mathrm{l}$ ) and creatinine levels (229 $\mu \mathrm{mol} / 1$, reference range: $44-115 \mu \mathrm{mol} / \mathrm{l}$ ) and marked weight loss $(\sim 10 \mathrm{~kg})$. The patient was treated with gliclazide (30 $\mathrm{mg}$ once daily) prior to hospitalization, prescribed by the community physician. The present study was approved by the Ethics Committee of the First Hospital of Jilin University. Written informed consent was obtained from the patient's guardian prior to the study. The patient reported no family history of diabetes or kidney disease. The patient reportedly had a varied healthy diet, and had not experienced diarrhea since childhood. Prior to hospitalization, the patient had presented with nausea and vomiting for $2 \mathrm{~h}$ but quickly recovered. Physical examination determined that the patient was $150 \mathrm{~cm}$ tall and weighed $35 \mathrm{~kg}$, with a body mass index of $15.56 \mathrm{~kg} / \mathrm{m}^{2}$ and presented with cephalus quadratus, rachitic rosary and a visible toe-out gait.

The patient and patient's guardian provided information regarding past medical history in order to understand the importance or chronicity of the previous rachitic findings. However, they did not provide any notable medical history to contribute to such findings. Laboratory examinations revealed that the patient's fasting plasma glucose level was $18.34 \mathrm{mmol} / \mathrm{l}$ (3.9-6.1 mmol/1), glycosylated hemoglobin was $11.3 \%$ (4-6\%) and fasting plasma C-peptide level was $2.85 \mathrm{nmol} / \mathrm{l}$ $(0.37-1.47 \mathrm{nmol} / \mathrm{l})$. No peak at $2 \mathrm{~h}$ postprandial was observed and diabetic autoimmune antibodies [islet cell cytoplasmic autoantibodies (ICA), glutamic acid decarboxylase autoantibodies (GADA), isulinoma-2-associated autoantibodies (IA2A) and insulin autoantibodies (IAA)] were negative. Serum sodium, potassium, calcium, phosphorus and magnesium were decreased and parathyroid hormone was markedly increased (serum PTH was 1,078.7 pg/ml, reference range: $12-88 \mathrm{pg} / \mathrm{ml}$ ). Serum uric acid was slightly increased. As the patients height and body weight were lower than peers $(14,15)$, pituitary axes testing was performed. TSH, FSH, LH, PRL and GH were slightly increased, whereas progesterone, testosterone and estradiol were within normal ranges (Table I). The level of serum creatinine was elevated, mild albuminuria $(0.74 \mathrm{~g} / 24 \mathrm{~h}$ urine) and a low proportion of urine ( $\leq 1.005)$ was observed. No other abnormal results in liver function were detected, with the exception of increased levels of serum alanine transaminase, aspartate transaminase, glutamyl tanspeptidase and alkaline phosphates. The patient also presented with low bone mass; bone mineral density indicated that the Z-scores of the spine (L1-L4) were between -0.8 and -2.0 and the Z-scores of the hip were <-2.0 (16) and cataracts. In a screening of OGTT, the mother and paternal uncle of the patient were diagnosed with diabetes; the sister and maternal uncle had impaired fasting glucose (IFG) and the paternal grandpa presented with impaired glucose tolerance (Fig. 1).
Table I. Examination data from the proband.

\begin{tabular}{|c|c|c|}
\hline Parameter & Results & $\begin{array}{l}\text { Normal } \\
\text { range }\end{array}$ \\
\hline Serum calcium, mmol/l & 1.60 & $2.1-2.6$ \\
\hline Serum phosphorus, $\mathrm{mmol} / \mathrm{l}$ & 0.72 & $0.8-1.6$ \\
\hline Serum potassium, mmol/1 & 3.27 & $3.5-5.1$ \\
\hline Serum magnesium, mmol/1 & 0.43 & $0.74-1.73$ \\
\hline $25(\mathrm{OH}) \mathrm{D} 3, \mathrm{ng} / \mathrm{ml}$ & 3.00 & 4-30 \\
\hline ALP, U/1 & 511.00 & $15-112$ \\
\hline $\mathrm{FPG}, \mathrm{mmol} / \mathrm{l}$ & 18.34 & $3.9-6.1$ \\
\hline $\mathrm{Cr}, \mu \mathrm{mol} / 1$ & 235.60 & $44-115$ \\
\hline $\mathrm{UA}, \mu \mathrm{mol} / 1$ & 488.00 & $210-430$ \\
\hline PTH, pg/ml & $1,078.70$ & $12-88$ \\
\hline ALT, U/l & 121.00 & $8-50$ \\
\hline $\mathrm{AST}, \mathrm{U} / 1$ & 101.00 & $8-40$ \\
\hline$\gamma-\mathrm{GT}, \mathrm{U} / 1$ & 101.00 & $5-54$ \\
\hline Serum albumin, g/l & 45.60 & $35-55$ \\
\hline $\begin{array}{l}\text { Urine calcium, } \\
\mathrm{mmol} / \mathrm{l} \text { ( } 24 \mathrm{~h} \text { urine })\end{array}$ & 1.45 & $2.5-7.5$ \\
\hline $\begin{array}{l}\text { Urine phosphorus, } \\
\mathrm{mmol} / \mathrm{l} \text { ( } 24 \mathrm{~h} \text { urine) }\end{array}$ & 1.80 & $22-48$ \\
\hline $\begin{array}{l}\text { Urine potassium, } \\
\mathrm{mmol} / \mathrm{l}(24 \mathrm{~h} \text { urine })\end{array}$ & 7.60 & $51-102$ \\
\hline $\begin{array}{l}\text { Urine chlorine, } \\
\mathrm{mmol} / \mathrm{l} \text { ( } 24 \mathrm{~h} \text { urine) }\end{array}$ & 85.80 & $100-250$ \\
\hline $\begin{array}{l}\text { Urine sodium, } \\
\mathrm{mmol} / \mathrm{l} \text { ( } 24 \mathrm{~h} \text { urine) }\end{array}$ & 116.60 & $130-260$ \\
\hline $\mathrm{TSH}, \mu \mathrm{IU} / \mathrm{ml}$ & 6.35 & $0.27-4.20$ \\
\hline $\mathrm{FSH}, \mathrm{mIU}, \mathrm{ml}$ & 25.45 & $1.27-19.26$ \\
\hline $\mathrm{LH}, \mathrm{mIU} / \mathrm{ml}$ & 11.78 & $1.24-8.62$ \\
\hline $\mathrm{PRL}, \mathrm{mIU} / \mathrm{ml}$ & 324.93 & $55.97-278.36$ \\
\hline $\mathrm{GH}, \mathrm{ng} / \mathrm{ml}$ & 1.517 & $0.003-0.971$ \\
\hline $\mathrm{PG}, \mathrm{nmol} / \mathrm{l}$ & 1.00 & $0.318-2.671$ \\
\hline $\mathrm{T}, \mathrm{nmol} / \mathrm{l}$ & 11.50 & $6.07-27.1$ \\
\hline $\mathrm{E} 2, \mathrm{pmol} / \mathrm{l}$ & 35.00 & $<73.4-172.49$ \\
\hline
\end{tabular}

$25(\mathrm{OH})$ D3, 25-hydroxyvitamin D3; ALP, alkaline phosphates; FPG, fasting plasma glucose; Cr, creatinine; UA, serum uric acid; PTH, parathyroid hormone; ALT, alanine transaminase; AST, aspartate transaminase; $\gamma$-GT, glutamyl tanspeptidase; TSH, thyroid-stimulating hormone; FSH, follicle-stimulating hormone; $\mathrm{LH}$, luteinizing hormone; PRL, prolactin; GH, growth hormone; PG, progesterone; $\mathrm{T}$, testosterone; E2, estradiol.

An abdominal computed tomography (CT) scan indicated a bilateral atrophic kidney with multiple renal cysts, primarily located at the junction of the renal cortex and medulla, with a diameter of 0.3-0.7 cm (Fig. 2A). The CT scan also revealed that the patient presented with hypogenesis of the tail and body of the pancreas (Fig. 2B). A kidney biopsy (Fig. 3) indicated that the mesangial cells and matrix were mildly hyperplastic, the partial glomerulars were expanding, the interstitial spaces of renal capsules were smaller, the epithelium of renal tubulars were undergoing vacuolar degeneration and renal tubules were atrophic. Furthermore, there was minimal dilatation 

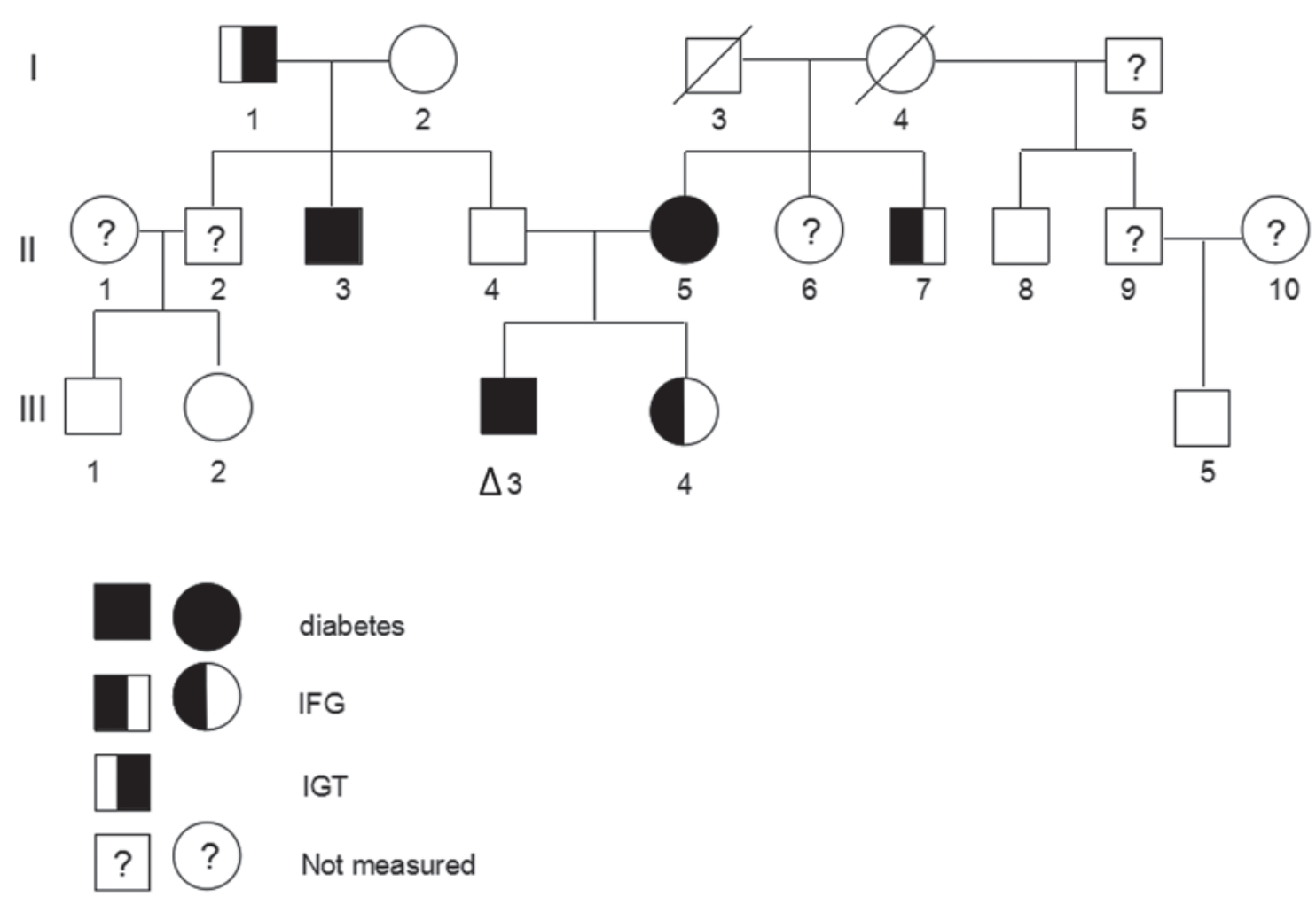

Figure 1. Pedigree and oral glucose tolerance test screening of the family (three generations I, II and III). Individuals with diabetes are indicated by solid squares (males) or circles (females), unaffected individuals are indicated by an open symbol. The half-filled symbol represents the individuals with IFG (left) or IGT (right). The proband is marked with $\Delta$ and slashes (/) indicate deceased individuals. The question mark (?) represents the individuals that did no undergo measurements. IFG, impaired fasting glucose; IGT impaired glucose tolerance.
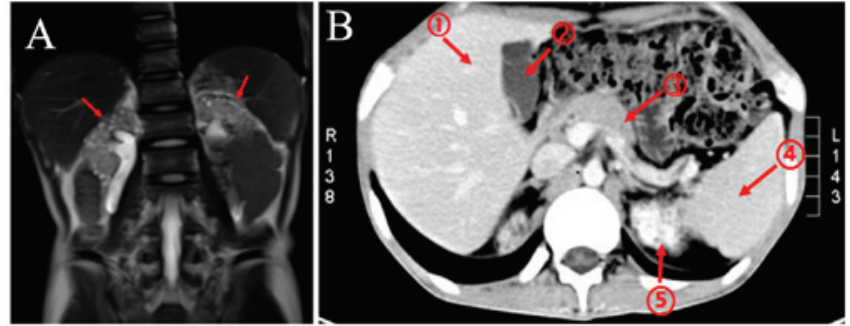

Figure 2. Computer tomography scans of the patient. (A) Arrows indicate kidneys with multiple renal cysts and (B) 1, liver; 2 , cholecyst; 3 , hypogenesis of the pancreas; 4 , spleen and 5 , kidney.

of the partial renal tubules, and slight fibrosis of the mesenchyme, which was filled with lymphocytes and monocytes was observed. Immunofluorescence determined that immunoglobulin and addiment were negative. TEM indicated that the foot processes of glomerular epithelial cells were merged segmentally, there were no electronic dense materials and the renal tubules and mesenchyme were normal (Fig. 3).

Patient treatment. Since the capacity for insulin secretion of the patient's pancreas was decreased, the liver and kidney functions were abnormal. Therefore, insulin therapy was prescribed. The basal insulin (glargine) initial dosage was 6 units (once daily by subcutaneous injection) and preprandial insulin (recombinant human insulin) was 4 units, administered 30 min before three meals. Daily, fingertip blood glucose was assessed seven times for the patient, and insulin dosage was adjusted following two days according the patients blood glucose levels. The insulin dosage was gradually adjusted from then. The final treatment was as follows: Basal insulin was 6 units and preprandial insulin was 8 units, which was used to keep the patients blood glucose under control.

Genetic testing. For the gene sequencing analysis, PCR was performed using specific primers of HNF1B gene, which were HNF1B-2F (5'-GGGGCAGTCACCTTCTCCT-3') and HNF1B-2R (3'-GGGGGCTGTGACTGAAGAACAT-5'). Genetic testing revealed an unreported amino acid mutation in exon 2 of HNF-1 $\beta$ (c.391C $>$ T), which is a nonsense mutation of CAA by TAA at codon 131 (Fig. 4). Genetic testing was also performed for the patient's family members and this mutation was not identified in any of the tested individuals (patients relatives: Father, mother, sister, paternal grandparents, two maternal uncles, two male cousins and one female cousin.).

Patient outcomes. Following discharge, the patient was prescribed insulin therapy (basal insulin was 6 units and preprandial insulin was 8 units) and treatment to correct the electrolyte disorder, as follows: $0.6 \mathrm{~g}$ calcium carbonate tablet, $0.25 \mu \mathrm{g}$ calcitriol capsule and $2 \mathrm{~g}$ potassium citrate three times daily, $100 \mathrm{ml}$ of $73.1 \mathrm{~g}$ disodium hydrogen phosphate and $6.4 \mathrm{~g}$ potassium dihydrogen phosphate dissolved in 1,000 $\mathrm{ml}$ water, once daily. Based on follow-up examinations (once every $\sim 3$ months), including plasma glucose, serum electrolytes, serum liver and kidney functions, the results were stable, so treatment was not changed. The patient's glucose control and quality of life were deemed to be satisfactory. 

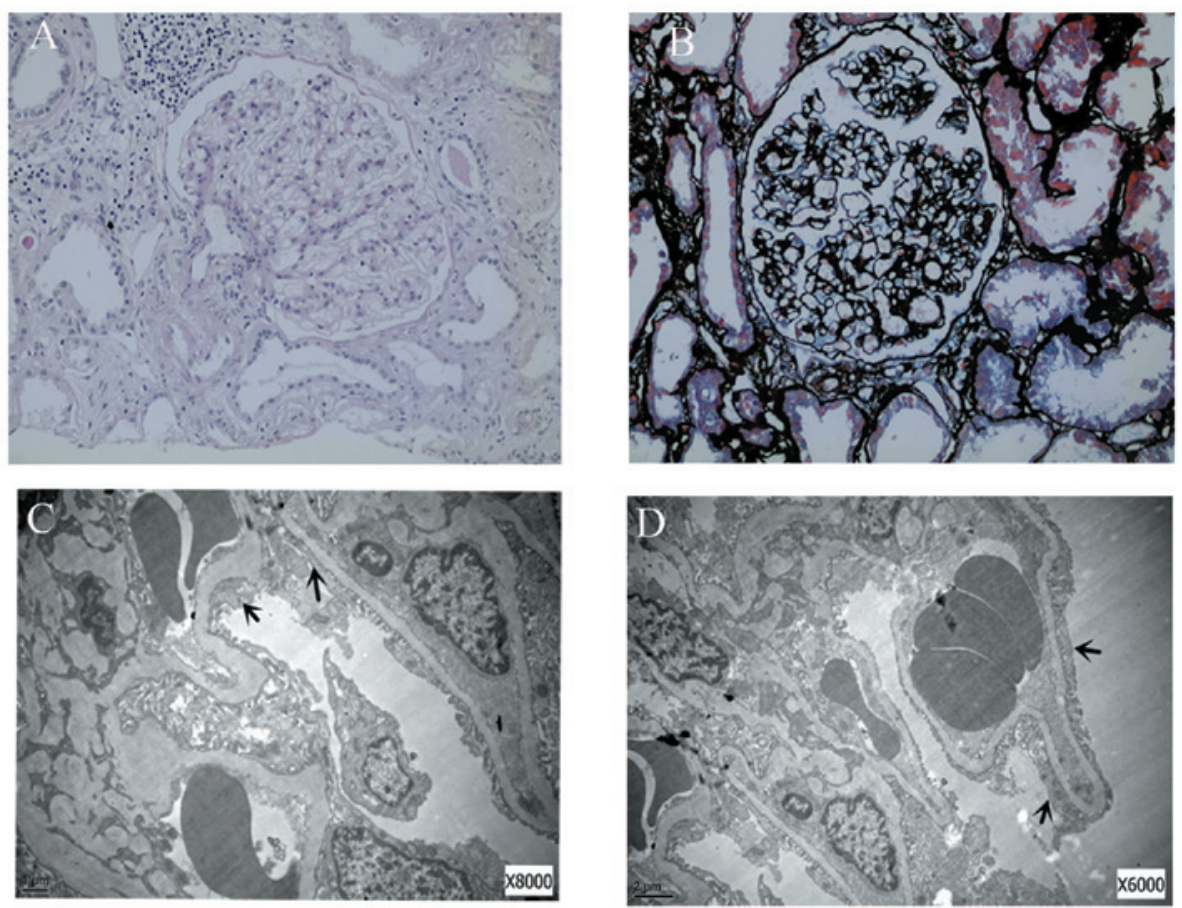

Figure 3. Results of the kidney biopsy by histopathology, light and electron microscopy. Light microscopy images of (A) PAS staining, and (B) PASM staining, at a magnification of 10x20. JEM-100 transmission electron microscopy of the kidney at a magnification of (C) x6,000 and (D) x8,000. The arrow indicates the segmental fusion of glomerular epithelium foot processes. PAS, periodic acid-schiff; PASM, periodic acid-silver metheramine.

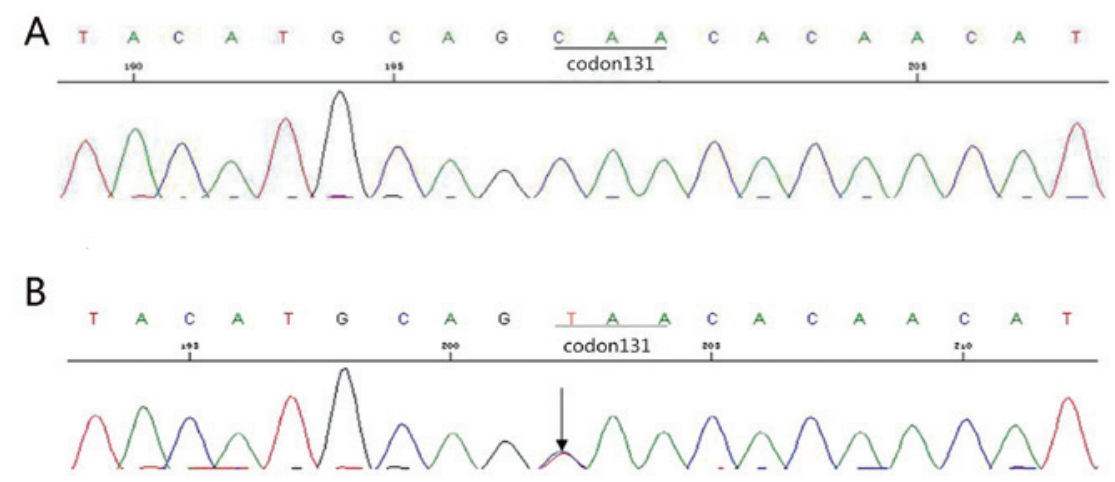

Figure 4. Sequence of the hepatocyte nuclear factor-1 $\beta$ gene. (A) The normal sequence. (B) The patient had a nonsense mutation; an arrow indicates the mutation site.

\section{Discussion}

Based on the medical history of the patient, physical examinations and laboratory evaluations, a MODY5 diagnosis was initially suspected. It was then determined that the patient had renal cysts and pancreatic agenesis, further indicating the presence of a HNF-1 $\beta$ mutation. Genetic screening confirmed the presence of a previously unreported amino acid mutation in exon 2 of HNF-1 $\beta$ in the patient.

It has been determined that HNF-1 $\beta$ serves a critical role in the development of various organs, including the liver, pancreas and kidney $(3,10)$. The most common phenotypes of the HNF-1 $\beta$ mutation are diabetes and renal disease, including multicystic dysplastic kidneys, noncystic renal parenchymal disease and oligomeganephronia $(9,17)$. Additionally, multiple renal cysts may result in renal tubule dysfunction and the increased secretion of serum ions, causing rachitis due to a serum calcium and phosphorus metabolite disorder.

HNF-1 $\beta$ is essential for the early development of the pancreas (18). Previous studies have indicated that HNF-1 $\beta$ mutation carriers have a small pancreas, which is attributable to hypoplasia, and pancreatic atrophy also can be observed in patients with MODY5 $(19,20)$. It has been reported that patients with HNF-1 $\beta$ gene mutations may also present with moderately lower exocrine pancreatic function (21). Pancreatic exocrine and endocrine functions seem to be directly dependent on the volume of the remaining working area of the pancreas (21). The 25-hydroxyvitamin D level of the proband was slightly decreased and, as demonstrated by the patient's medical history, no symptoms of pancreatic exocrine dysfunction were identified; therefore the clinical manifestations may be primarily due to a long-term electrolyte disturbance. In addition, HNF-1 $\beta$ may activate the transcription of glucose 
transporter-2, liver-type pyruvate kinase and insulin genes; therefore, its mutation decreases transcription and impairs the secretion of insulin (22).

The patient's secondary sex characteristics were well-developed and the bone epiphysis was closed. The HNF-1 $\beta$ mutation does not affect bone formation directly, but in this case, the multiple renal cysts increased secretion of serum electrolytes, especially serum calcium and phosphorus, so it induced growth retardation. The patient presented with a slightly increased level of gonadotrophins and other pituitary hormones, which may be caused by the stress associated with severe electrolyte disorders. In response to stress, the various hormones level changes. Reactions to stress are associated with enhanced secretion of a number of hormones including glucocorticoids, catecholamines, growth hormone and prolactin (23). The patient had slightly increased pituitary hormones, but with nearly normal target gland hormones, which might be caused by the stressful situation associated with severe electrolyte disorders.

In conclusion, numerous MODY5 cases have been reported, however MODY5 cases with pancreas agenesis are rare $(10,17,24,25)$, they present with various changes in structure and function in different organs. Therefore, the present study suggests that screening for HNF-1 $\beta$ should be performed when young diabetic patients also present with multiple renal cysts. Genetic testing may prevent misdiagnoses of type I or type II diabetes and in turn, guide appropriate treatment.

\section{Acknowledgements}

The present study was supported by Fund for Jilin Province Development and Reform Commission (grant no. 2013C036-4) and the Specialized Research Fund for the Doctoral Program of Higher Education (grant no. 20130061110072).

\section{References}

1. Tattersall RB: Mild familial diabetes with dominant inheritance. Q J Med 43: 339-357, 1974.

2. Bonnefond A, Philippe J, Durand E, Dechaume A, Huyvaert M, Montagne L, Marre M, Balkau B, Fajardy I, Vambergue A, et al: Whole-exome sequencing and high throughput genotyping identified KCNJ11 as the thirteenth MODY Gene. PLoS One 7: e37423, 2012.

3. Gardner DS and Tai ES: Clinical features and treatment of maturity onset diabetes of the young (MODY). Diabetes Metab Syndr Obes 5: 101-108, 2012.

4. Shepherd M, Ellis I, Ahmad AM, Todd PJ, Bowen-Jones D, Mannion G, Ellard S, Sparkes AC and Hattersley AT: Predictive genetic testing in maturity-onset diabetes of the young (MODY). Diabet Med 18: 417-421, 2001.

5. Shepherd M, Shields B, Hammersley S, Hudson M, McDonald TJ, Colclough K, Oram RA, Knight B, Hyde C, Cox J, et al: Systematic population screening, using biomarkers and genetic testing, identifies $2.5 \%$ of the U.K. pediatric diabetes population with monogenic diabetes. Diabetes Care 39: 1879-1888, 2016

6. Hattersley AT and Patel KA: Patel1: Precision diabetes: Learning from monogenic diabetes. Diabetologia 60: 769-777, 2017.

7. Longo DL, Fauci A, Kasper D, Hauser SL, Jameson JL and Loscalzo J: Harrison's Principles of Internal Medicine. Shanahan JF and Davis KJ (eds). 18th edition. McGraw-Hill, New York, NY, 2012.
8. Bellanne-Chantelot C, Clauin S, Chauveau D, Collin P, Daumont M, Douillard C, Dubois-Laforgue D, Dusselier L, Gautier JF, Jadoul M, et al: Large genomic rearrangements in the hepatocyte nuclear factor-1beta (TCF2) gene are the most frequent cause of maturity-onset diabetes of the young type 5 . Diabetes 54: 3126-3132, 2005.

9. Horikawa Y,IwasakiN,Hara M,FurutaH,Hinokio Y,Cockburn BN, Lindner T, Yamagata K, Ogata M, Tomonaga O, et al: Mutation in hepatocyte nuclear factor-1 beta gene (TCF2) associated with MODY. Nat Genet 17: 384-385, 1997.

10. Alvelos MI, Rodrigues M, Lobo L, Medeira A, Sousa AB, Simão C and Lemos MC: A novel mutation of the HNF1B gene associated with hypoplastic glomerulocystic kidney disease and neonatal renal failure: A case report and mutation update. Medicine (Baltimore) 94: e469, 2015.

11. Shields BM, Hicks S, Shepherd MH, Colclough K, Hattersley AT and Ellard S: Maturity-onset diabetes of the young (MODY): How many cases are we missing? Diabetologia 53: 2504-2508, 2010.

12. Kolatsi-Joannou M, Bingham C, Ellard S, Bulman MP, Allen LI, Hattersley AT and Woolf AS: Hepatocyte nuclear factor-1beta: A new kindred with renal cysts and diabetes and gene expression in normal human development. J Am Soc Nephrol 12: 2175-2180, 2001.

13. Musetti C, Quaglia M, Mellone S, Pagani A, Fusco I, Monzani A, Giordano $M$ and Stratta P: Chronic renal failure of unknown origin is caused by HNF1B mutations in $9 \%$ of adult patients: A single centre cohort analysis. Nephrology (Carlton) 19: 202-209, 2014.

14. Zhang S, Zhang Jiye, MA Z, Liu G, Han Y, Shen X and Xu R: The growth charts of height, weight and body mass index for skeletal age in adolesce. Chin J Forensic Med 24: 308-311, 2009.

15. Zong X, Li H, Zhang Y and Zhang H: Retrospective mixed-longitudinal study on the growth trajectory of height among children and adolescents. Zhonghua Er Ke Za Zhi 52: 655-661, 2014 (In Chinese).

16. Cosman F, de Beur SJ, LeBoff MS, Lewiecki EM, Tanner B, Randall S and Lindsay R; National Osteoporosis Foundation: Clinician's guide to prevention and treatment of osteoporosis. Osteoporos Int 25: 2359-2381, 2014.

17. Jo W, Sano H, Sudo A, Matsunami Y, Kawamura N and Tajima T: A case of novel mutation of HNF1B in maturity-onset diabetes of the young type 5 (MODY5). Clin Pediatr Endocrinol 21: 53-55, 2012.

18. Haumaitre C, Barbacci E, Jenny M, Ott MO, Gradwohl G and Cereghini S: Lack of TCF2/vHNF1 in mice leads to pancreas agenesis. Proc Natl Acad Sci USA 102: 1490-1495, 2005.

19. Ulinski T, Lescure S, Beaufls S, Guigonis V, Decramer S, Morin D, Clauin S, Deschênes G, Bouissou F, Bensman A and Bellanné-Chantelot C: Renal phenotypes related to hepatocyte nuclear factor-1beta (TCF2) mutations in a pediatric cohort. J Am Soc Nephrol 17: 497-503, 2006.

20. Chen YZ, Gao Q, Zhao XZ, Chen YZ, Bennett CL, Xiong XS, Mei CL, Shi YQ and Chen XM: Systematic review of TCF2 anomalies in renal cysts and diabetes. Chin Med J (Engl) 123: 3326-3333, 2010.

21. Tjora E, Wathle G, Erchinger F, Engjom T, Molven A, Aksnes L, Haldorsen IS, Dimcevski G, Raeder H and Njølstad PR: Exocrine pancreatic function in hepatocyte nuclear factor $1 \beta$-maturity-onset diabetes of the young (HNF1B-MODY) is only moderately reduced: Compensatory hypersecretion from a hypoplastic pancreas. Diabet Med 30: 946-955, 2013.

22. Okita K, Yang Q, Yamagata K, Hangenfeldt KA, Miyagawa J, Kajimoto Y, Nakajima H, Namba M, Wollheim CB, Hanafusa T and Matsuzawa Y: Human insulin gene is a target gene of hepatocyte nuclear factor-1alpha (HNF-1alpha) and HNF-1beta. Biochem Biophys Res Commun 263: 566-569, 1999.

23. Ranabir S and Reetu K: Stress and hormones. Indian J Endocrinol Metab 15: 18-22, 2011.

24. Haumaitre C, Fabre M, Cormier S, Baumann C, Delezoide AL and Cereghini S: Severe pancreas hypoplasia and multicystic renal dysplasia in two human fetuses carrying novel HNF1beta/MODY5 mutations. Hum Mol Genet 15: 2363-2375, 2006.

25. Thirumalai A, Holing E, Brown Z and Gilliam LK: A case of hepatocyte nuclear factor-1 $\beta$ (TCF2) maturity onset diabetes of the young misdiagnosed as type 1 diabetes and treated unnecessarily with insulin. J Diabetes 5: 462-464, 2013. 